\title{
Penerapan Six Sigma Untuk Peningkatan Kualitas Packing Pada Minyak Goreng Pouch PT. XYZ Di Kabupaten Gresik
}

\author{
Yitno Utomo ${ }^{1}$ dan Rahmatulloh ${ }^{2}$ \\ ${ }^{1,2}$ Fakultas Teknik, Universitas PGRI Adi Buana, Jl Dukuh Menanggal XII Surabaya, Indonesia, 60234 \\ Correspondence: Yitno Utomo (yitno@ mipasby.ac.id) (081556500828), Rahmatulloh \\ (rahmatulloh0095@gmail.com) (082132219055)
}

Received: 170721 - Revised: 090821 - Accepted: 100921 - Published: 150921

\begin{abstract}
Abstrak. Kualitas kemasan sangat berpengaruh terhadap pendistribusian hasil produksi kepada pelanggan. Apabila kemasan mengalami kerusakan atau cacat ketika produksi, maka produk tersebut tidak dapat didistribusikan kepada konsumen. Oleh karena itu, kualitas dari kemasan harus dijaga untuk keberhasilan pemasaran produk. Hal ini berlaku untuk setiap produk tidak terkecuali produk minyak goreng dengan kemasan pouch. Pada proses packingnya kemasan pouch sering mengalami kendala atau cacat sehingga dapat merugikan perusahaan. Tujuan dari penelitian ini untuk mengetahui hasil analisis six sigma sebelum diterapkannya DMAIC, dan mengetahui hasil analisis implementasi six sigma sesudah diterapkannya DMAIC. Pengambilan sampel dalam penelitian ini menggunakan teknik purposive sampling, yang diambil selama 30 hari. Data dalam penelitian ini diperoleh melalui wawancara, dan observasi saat penelitian berlangsung dimana kehadiran peneliti sangat diperlukan dalam penelitian ini. Teknik analisis yang digunakan yaitu dengan metode DMAIC. Define, mengidentifikasi masalah guna mengetahui sumber permasalahan dan pembuatan diagaram IPO; Measure, melakukan pengukuran menggunakan diagram control P-chart dan menganalisa tingkat DPMO; Analyze, mengidentifikasi penyebab dengan menggunakan diagram pareto dan diagram tulang ikan; Improve, rekomendasi usulan perbaikan; Control, mengevaluasi hasil kinerja dalam kondisi standart dan terjaga nilainilai peningkatannya. Hasil penelitian menunjukkan sebelum dilakukan perbaikan nilai sigma yang didapat yaitu 3,99 sigma dengan nilai DPU sebesar 0,006434 dan DPMO sebesar 6.364. Terdapat 4 jenis defect yang masuk dalam CTQ yaitu bocor, isi kurang, kemasan rusak, dan expired date tidak ada. Setelah melakukan 9 tindakan perbaikan diperoleh nilai sigma seberas 4,18 dengn nilai DPU sebesar 0,003655 dan DPMO sebesar 3.655
\end{abstract}

Kata kunci: Six Sigma, DMAIC, Cacat Produk.

Citation Format: Citation Format: Utomo, Y., Rahmatulloh. (2021). Penerapan Six Sigma Untuk Peningkatan Kualitas Packing Pada Minyak Goreng Pouch PT. XYZ Di Kabupaten Gresik (SENAM), 2021, 09-23 


\section{PENDAHULUAN}

Kualitas kemasan sangat berpengaruh terhadap pendistribusian hasil produksi kepada pelanggan. Apabila kemasan mengalami kerusakan atau cacat ketika produksi, maka produk tersebut tidak dapat didistribusikan kepada konsumen. Oleh karena itu, kualitas dari kemasan harus dijaga untuk keberhasilan pemasaran produk. Mulai dari penerimaan kemasan dari supplier hingga pada proses packing. Proses pengisian dan pengepakan (packing) dilakukan di unit Filling produksi. Masing-masing jenis kemasan memiliki unit filling yang berbeda-beda.

Penyimpangan-penyimpangan yang ditemukan bisa berupa kemasan bocor, isi tidak sesuai, desain kemasan salah, kode produksi/experied tidak ada atau ditemukannya benda asing dalam produk. Semakin banyaknya produk reject maka semakin banyak pula kerugian yang ditanggung oleh perusahaan. Mulai dari penyusutan jumlah minyak yang harus melalui proses packing ulang, kemasan pouch yang rusak harus di reject, dan kemasan karton yang reject akibat basah minyak karena pouch yang bocor. Sehingga diperlukan metode yang tepat untuk mengurangi nonconforming agar kerugian perusahaan dapat ditekan seminimum mungkin.

Studi yang dilakukan oleh Park mengekspresikan bahwa perusahaan dapat menerapkan strategi bisnis dengan metode six sigma untuk meningkatkan kinerja perusahaan (Park, 2002). Metode six sigma telah banyak diaplikasikan dalam rangka peningkatan kinerja, seperti industri manufaktur (Linderman, dkk., 2003), kesehatan dan keselamatan (Rimantho \& Cahyadi, 2016; Sanjit, dkk., 2011), sistem manajemen lingkungan (Calia, dkk., 2009). Six sigma metode memiliki banyak nilai-nilai dasar seperti prinsip-prinsip perbaikan proses, metode statistik, manajemen sistem, perbaikan terus-menerus dan perbaikan terkait keuangan. Terdapat lima tahapan DMAIC sebagai karakteristik pada Six Sigma, antara lain, Define-Measure - Analyze - Improve - Control.

Dino Rimantho dan Desak Made Mariani (2017), menggunakan metode six sigma untuk mengendalikan kualitas air baku pada produksi makanan. Nilai sigma sebelum dilakukan perbaikan adalah 3.3 dengan kemugkinan kegagalan sebesar 34491 untuk sejuta proses. Perbaikan dilakukan dengan FMEA pada nilai RPN tertinggi yaitu pada filter dan diperoleh nilai sigma menjadi 4.09 dengan kemugkinan kegagalan proses sebesar 5526 untuk sejuta proses. 
Tujuan dari penelitian ini yaitu untuk mengetahui hasil analisis six sigma sebelum diterapkannya DMAIC dan mengetahui hasil analisis implementasi six sigma sesudah diterapkannya DMAIC.

\section{METODE PELAKSANAAN}

Populasi dalam penelitian ini adalah produk minyak goreng pouch kemasan $1 \mathrm{~L}$ yang diproduksi oleh PT. XYZ selama periode Tahun 2020-2021. Sedangkan dalam pengambilan sampel menggunakan teknik puposive sampling. Adapun sampel yang digunakan dalam penelitian ini adalah produk minyak goreng kemasan pouch 1L dari PT. XYZ yang ditemukan mengalami cacat dan terdata oleh bagian Quality Control selama 30 hari di Tahun 2020.

Metode analisis data yang digunakan mengacu pada prinsip-prinsip yang terdapat dalam metode Six Sigma. Metode ini digunakan untuk mengantisipasi terjadinya kesalahan atau defect dengan menggunakan langkah-langkah terukur dan terstruktur. Metode six sigma yang digunakan yaitu metode six sigma-DMAIC (Define, Measure, Analyze, Improve and Control).

Adapun langkah-langkah dalam pengolahan data dengan metode Six Sigma 5 siklus DMAIC (Define,Measure, Analyze, Improve, and Control) adalah sebagai berikut :

\section{Define}

Pada tahapan ini ditentukan proporsi defect yang menjadi penyebab paling signifikan terhadap adanya kerusakan yang merupakan sumber masalah paling besar sehingga ditemukan produk minyak goreng kemasan pouch $1 \mathrm{~L}$ yang cacat. Cara yang ditempuh adalah:

1. Mendefinisikan masalah standar kualitas dalam menghasilkan produk yang telah ditentukan perusahaan.

2. Mengidentifikasi masalah dan kerusakan apa yang terjadi pada produk minyak goreng kemasan pouch $1 \mathrm{~L}$, guna mengetahui penyebab terbesar yang menjadi sumber masalah.

3. Perumusan masalah, menetapkan masalah yang akan menjadi objek penelitian di dalam penelitian tersebut.

4. Pembuatan diagram IPO, sekaligus menentukan factor input yang berperan penting dalam proses packing produk. 


\section{Measure}

Tahap pengukuran yang dilakukan melalui dua tahap dengan pengambilan sampel yang dilakukan perusahan sebagai berikut :

1. Analisis diagram control (P-Chart)

Diagram kontrol $\mathrm{P}$ digunakan untuk atribut yaitu pada sifat- sifat barang yang didasarkan atas proporsi jumlah suatu kejadian atau kejadian seperti diterima atau ditolak akibat proses produksi.

Rumus proporsi kerusakan :

$$
P=\frac{p_{i}}{n_{i}}
$$

Keterangan :

$\mathrm{P}=$ proporsi kerusakan

$p_{i}=$ proporsi kerusakan setiap produk

$n_{i}=$ proporsi produksi

Rumus menghitung garis pusat $p$-chart :

$$
\bar{p}=\frac{\sum p_{i}}{\sum n_{i}}
$$

Keterangan :

$\bar{p}=$ Garis pusat peta kendali proporsi kerusakan

$p_{i}=$ proporsi produk rusak setiap produk

$n_{i}=$ proporsi produksi

Menentukan nilai UCL (Upper control limit/batas kendali atas) dan LCL (Lower control limit/ batas kendali bawah) menggunakan metode rata-rata :

$$
\begin{gathered}
U C L=\bar{p}+\sqrt[3]{\frac{\bar{p}(1-\bar{p})}{n_{i}}} \\
U C L=\bar{p}-\sqrt[3]{\frac{\bar{p}(1-\bar{p})}{n_{i}}}
\end{gathered}
$$

Keterangan :

$\mathrm{UCL}=$ Upper control limit /batas kendali atas

$\mathrm{LCL}=$ Lower control limit/ batas kendali bawah

$\bar{p}=$ Garis pusat peta kendali proporsi kerusakan

$n_{i}=$ proporsi produksi 
2. Menganalisa tingkat Defect Per Million Opportunitiess perusahaan.

a. Menghitung DPU (Defect per unit)

$$
D P U=\frac{\text { jumlah defect }}{\text { jumlah produksi }}
$$

b. Menghitung DPMO (Defect per million opportunities)

$$
D P M O=\frac{\text { jumlah defect }}{\text { jumlah produksi }} \times 1.000 .000
$$

\section{Analyze}

Analyze merupakan tahap operasional ketiga dalam peningkatan kualitas Six Sigma. Hal-hal yang dilakukan adalah sebagai berikut:

a. Pembuatan diagram Pareto

b. Pembuatan diagram tulang ikan

Diagram Pareto dirancang untuk mengetahui CTQ yang memiliki banyaknya cacat terbesar. Dengan demikian dapat dilakukan penentuan prioritas CTQ yang hendak diperbaiki.

\section{Improve}

Tahap keempat metodologi DMAIC adalah Improve. Tahap improve merupakan rencana tindakan untuk melaksanakan tindakan perbaikan dan peningkatan kualitas produk yang dihasilkan setelah mengetahui penyebab kerusakan atas terjadinya jenis-jenis kerusakan produk. Maka disusun suatu rekomendasi atau usulan tindakan perbaikan secara umum dalam upaya menekan tingkat kerusakan produk.

\section{Control}

Tahapan control bertujuan untuk mengevaluasi hasil kinerja dalam kondisi standar dan terjaga nilai-nilai peningkatannya yang kemudian didokumentasikan dan disebarluaskan yang berguna sebagai langkah perbaikan.

\section{HASIL DAN PEMBAHASAN}

Data yang dikumpulkan pada penelitian ini yaitu data produksi dan data produk cacat pada proses packing minyak goreng kemasan pouch 1 L periode 1 - 30 Desember 
2020. Dari data pengamatan selama 30 hari atau 30 kali pengamatan terdapat 10 jenis cacat pada produk minyak goreng pouch kemasan 1 liter. Dari 5.118 .564 produk yang diproduksi selama 30 hari terdapat 32.576 produk yang reject akibat cacat. Sehingga diperoleh prosentase cacat produk periode 01-30 Desember 2020 yaitu sebesar 0,64\%.

\section{Tahap Define}

Tahap define merupakan langkah awal dalam pelaksanaan metodologi six sigma. Define bertujuan untuk mengidentifikasi produk ataupun proses yang akan diperbaiki. Jenisjenis cacat yang ditemukan pada proses packing minyak goreng kemasan pouch 1 liter dapat kita lihat dimana terdapat 10 jenis cacat produk yang ditemukan pada periode 01-30 Desember 2020.

Tentunya banyak sekali faktor yang berpengaruh dalam proses packing ini. Berikut adalah gambar digram IPO dari proses packing minyak goreng pouch 1 liter :

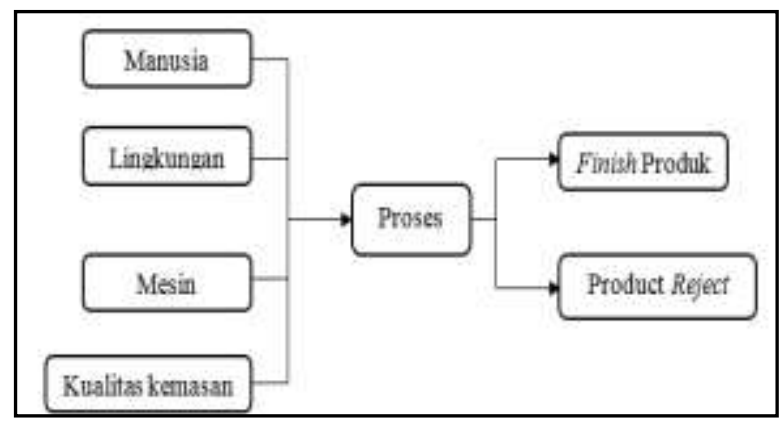

Gambar 1. Diagram IPO Proses packing

Dari diagram diatas maka dapat diketahui terdapat 4 faktor input yang berpengaruh dalam proses filling produk minyak goreng pouch yaitu :

1. Manusia : karyawan yang bekerja di bagian filing produk, baik pada bagian dozing tank, packing, maupun operator dan quality control yang mengontrol berjalanya proses filling produk.

2. Lingkungan : lingkungan dalam produksi filling produk, mulai dari area packing, area timbang, area filling minyak dan area seal.

3. Mesin : mesin yang digunakan dalam proses filling produk.

4. Kualitas kemasan : kemasan pouch 1 liter yang digunakan di PT. XYZ.

Berdasarkan masalah dari hasil pengamatan terdapat 10 jenis cacat yang ditemukan yaitu :

1. Kemasan rusak : terdapat cacat berupa sobekan, plastik laminasi mengelupas, goresan, atau yang lainnya pada kemasan sebelum digunakan. 
2. Sablon rusak : gambar yang nampak pada kemasan tidak jelas, warna kabur.

3. Warna tidak sesuai yang diminta : warna kemasan tidak sesuai dengan standart warna yang telah ditetapkan.

4. Kemasan bocor : kurangnya pemanasan ketika memasuki mesin seal, rentan waktu yang pendek ketika melewati mesin seal, bocor akibat terkena benda tajam atau kemasan melipat ketika melewati mesin seal.

5. Kemasan mengkerut : kemasan mengkerut akibat pemanasan yang berlebihan ketika melewati mesin seal.

6. Isi tidak sesuai : Berat produk lebih ringan atau lebih berat dari spesifikasi produk yang telah ditentukan.

7. Desain kemasan salah : desain kemasan yang digunakan ketika filing produk tidak sesuai dengan apa yang diminta.

8. Kode pruduksi / Expired Date tidak ada : kode produksi tidak tampak atau samar sehingga tidak bisa dilihat oleh mata, atau kode produksi salah tidak sesuai dengan tanggal ketika produksi.

9. Adanya benda asing : ditemukannya benda asing pada finish product. Benda asing disini adalah benda selain minyak goreng. Bisa berupa bintik hitam (kotoran yang lolos dari filter), tissue, atau serpihan majun.

10. Kemasan berbau : timbul bau tidak sedap atau menyengat yang berasal dari kemasan ketika dilakukan proses filling

\section{Tahap Measure}

Pada tahap measure ini pengukuran variasi data variabel dan atribut dengan membuat peta control dan menentukan level sigma dengan DPMO (Defect Per Milion Opportunities).

Berikut adalah penentuan P-chart dari data hasil pengamatan periode 01-30 Desember 2020, sebelum dilakukannya perbaikan : 
p-Chart for variabel defect

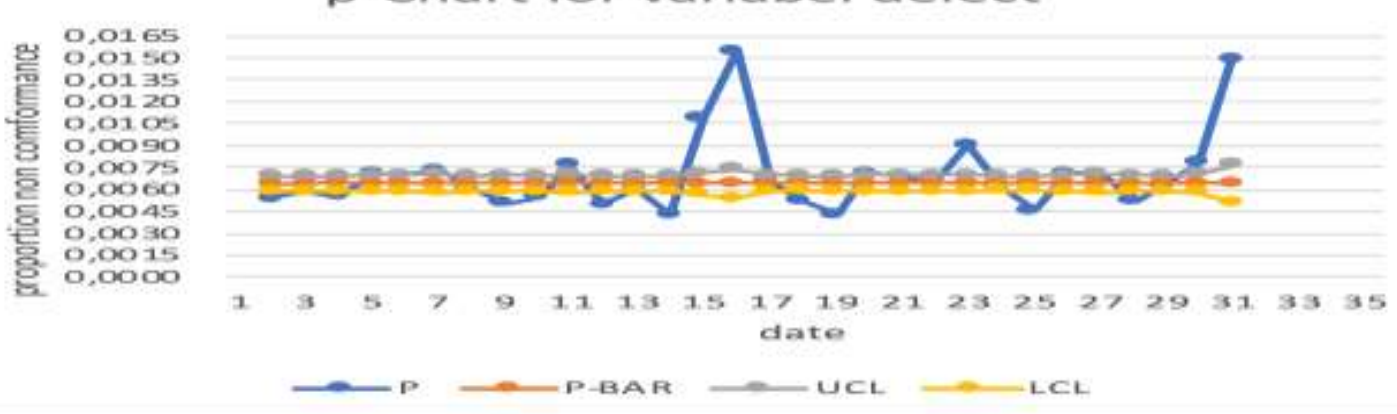

Gambar 2. Diagram P-chart periode 01-30 Desember 2020

Menganalisa tingkat Defect Per Million Opportunities perusahaan.

a. Menghitung DPU (Defect per unit)

$$
\begin{gathered}
D P U=\frac{\text { jumlah defect }}{\text { jumlah produksi }} \\
D P U=\frac{32.576}{5.118 .564} \\
D P U=0,00636
\end{gathered}
$$

b. Menghitung DPMO (Defect per million opportunities)

$$
\begin{gathered}
D P M O=\frac{\text { jumlah defect }}{\text { jumlah produksi }} \times 1.000 .000 \\
D P M O=0,006364 \times 1.000 .000 \\
D P M O=6.364
\end{gathered}
$$

Dari perhitungan diatas diperoleh DPU sebesar 0,006434 dan DPMO sebesar 6.364.

Sedangan nilai level sigma diperoleh melalui perhitungan konversi nilai sigma dari DPMO dengan menggunakan Michrosoft Exel. Dengan rumus sebagai berikut :

Level sigma $=$ NORMSINV $\left(\frac{(1.000 .000-D P M O)}{1.000 .000}\right)+1,5$

Sehingga level sigma yang diperoleh adalah

Level sigma $=$ NORMSINV $\left(\frac{(1.000 .000-6,364)}{1.000 .000}\right)+1,5$

Level sigma $=3,99$

\section{Tahap Analyze}

Pada tahap ini akan dilakukan proses identifikasi terhadap defect yang telah ditemukan pada proses filing produk minyak goreng pouch kemasan 1 liter untuk menemukan defect mana yang nantinya akan menjadi CTQ. 


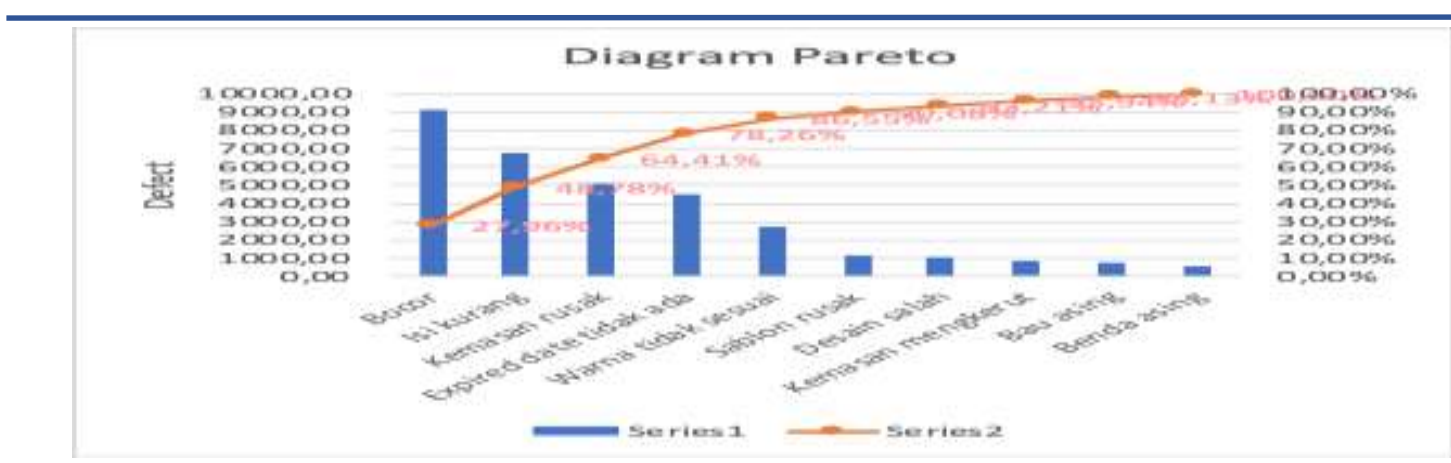

Gambar 3. Diagram Pareto periode 01-30 Desember 2020

Setelah dibuat diagram pareto langkah selanjutnya yaitu mengidentifikasi CTQ. Identifikasi CTQ dilakukan dengan cara memprosentasekan jumlah kecacatan tiap-tiap defect yang tercatat dengan total cacat secara keseluruhan. Untuk memilih CTQ dilakukan dengan memilih cacat yang prosentase komulatif mencapai kurang lebih 80\%, dan mengabaikan sisanya yang $20 \%$ yang bisa dilakukan dengan diagram pareto.

Dari diagram diatas diperoleh jenis-jenis defect yang masuk dalam CTQ yaitu bocor, isi kurang, kemasan rusak, dan expired date / kode produksi tidak ada. Berikut adalah diagram tulang ikan untuk masing-masing defect.

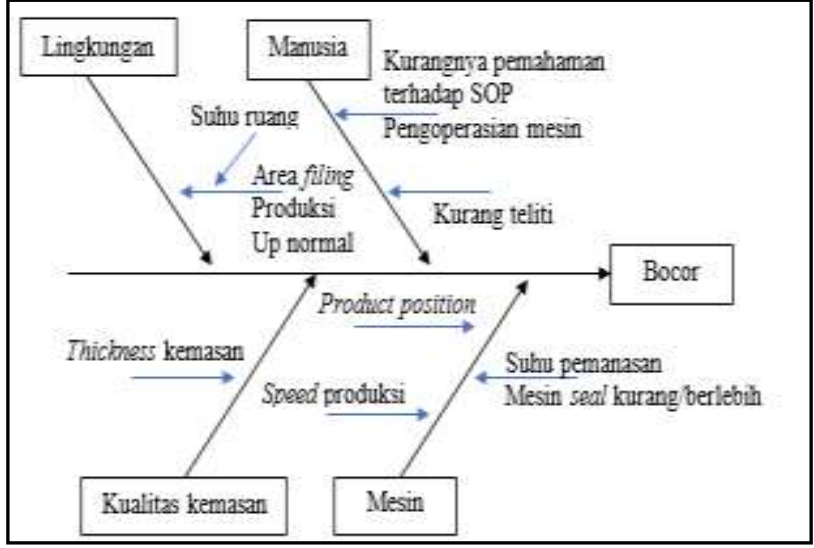

Gambar 4. Diagram tulang ikan defect bocor

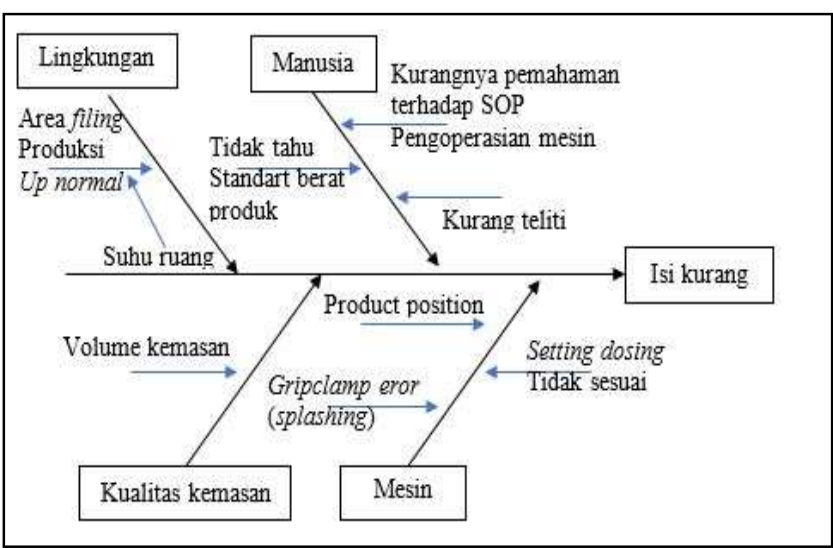

Gambar 5. Diagram tulang ikan defect isi kurang 


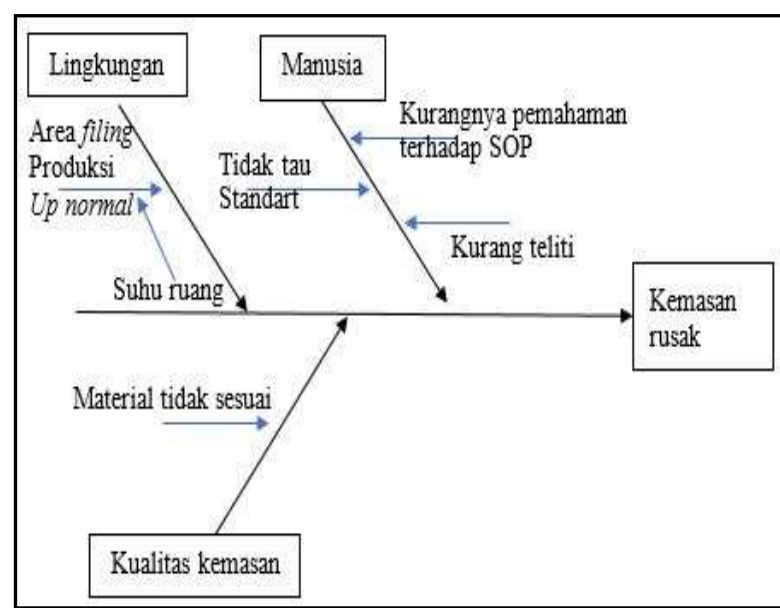

Gambar 6. Diagram tulang ikan defect kemasan rusak

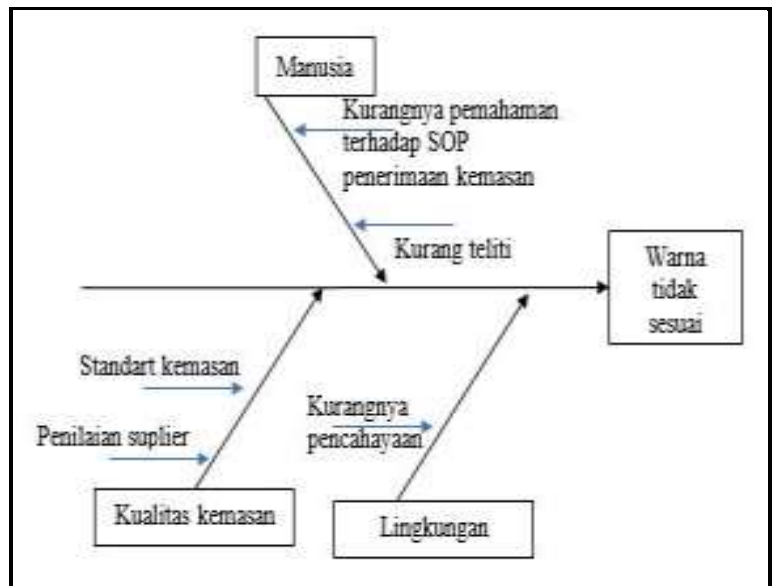

Gambar 8. Diagram tulang ikan defect warna kemasan tidak sesuai
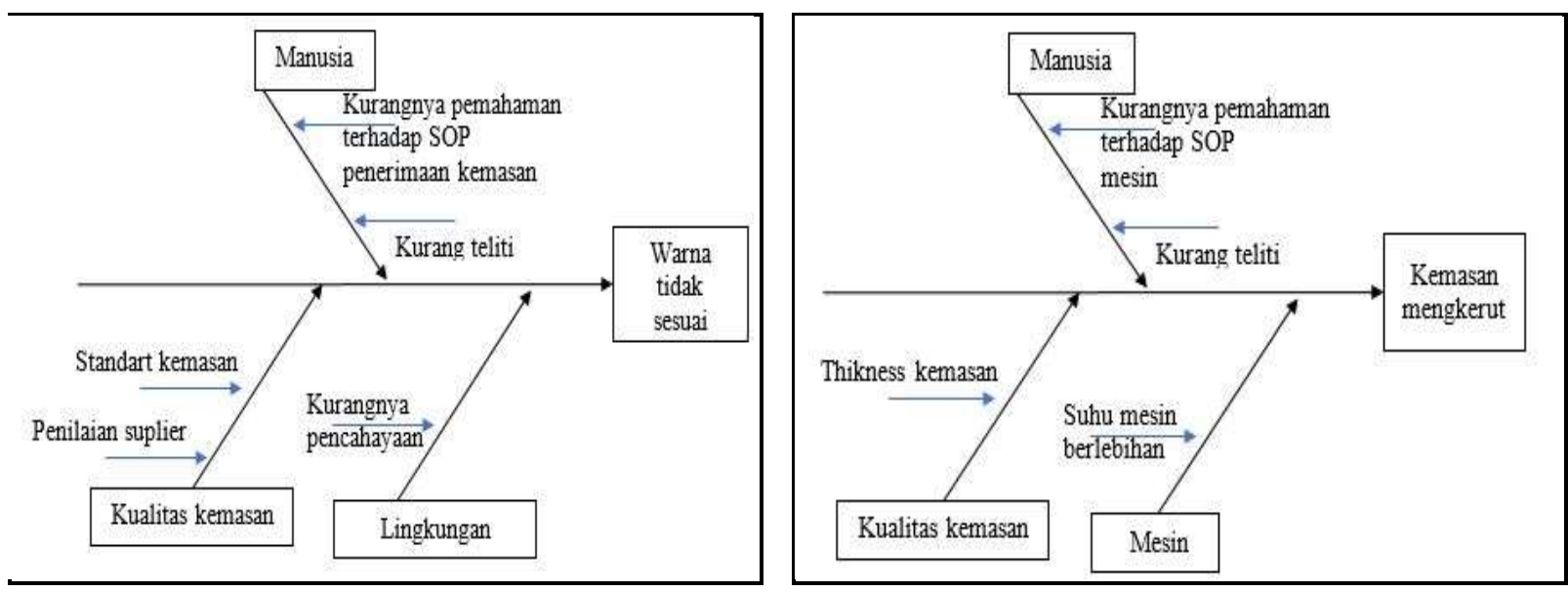
Gambar 10. Diagram tulang ikan defect desain kemasan salah

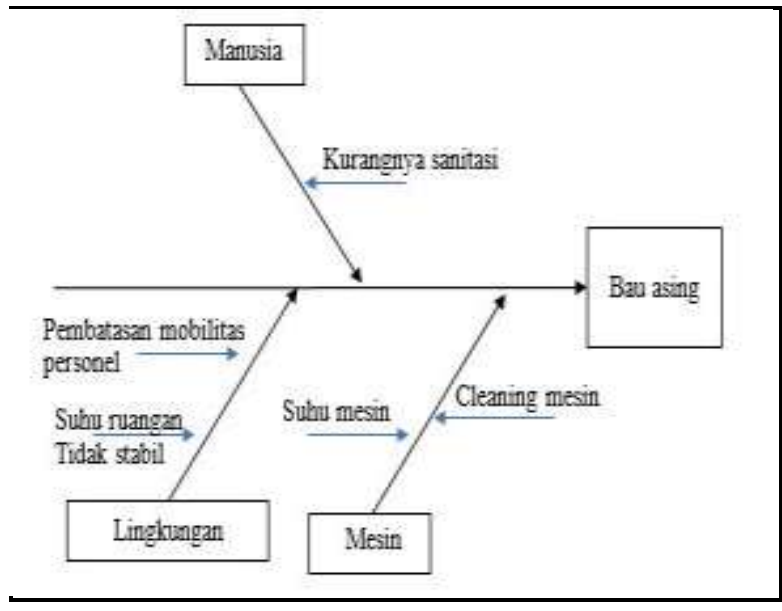

Gambar 12. Diagram tulang ikan defect kemasan berbau / bau asing
Gambar 11. Diagram tulang ikan defect kemasan mengkerut

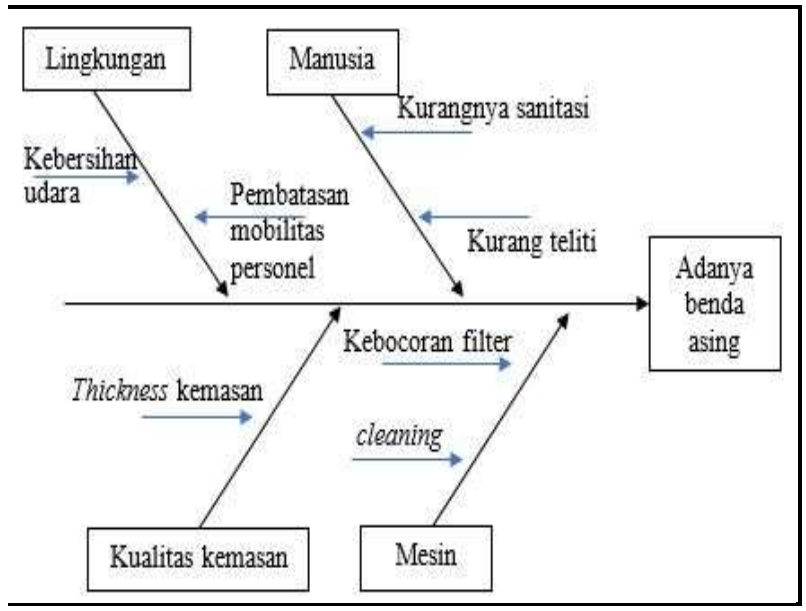

Gambar 13. Diagram tulang ikan defect adanya benda asing

\section{Tahap Improve}

Selanjutnya yaitu dilakukan pemilihan alternatif perbaikan yang memungkinkan untuk dapat dilakukan alternatif perbaikan yang dilakukan peneliti yaitu sebagai berikut :

1. Melaksanakan kegiatan training pengoperasian mesin yang diikuti oleh operator filling, terutama bagi operator baru.

2. Melaksanakan kegiatan training management waktu yang diikuti oleh seluruh karyawan yang bekerja di filling bagian proses.

3. Trial mesin untuk menentukan speed mesin dan suhu mesin seal.

4. Penunjukan PIC untuk pembuatan product spec kemasan dan produk spec jadi.

5. Kontrol suhu ruangan secara berkala.

6. Penambahan personel maintenance (untuk pengecekan mesin secara berkala, dan service mesin secara berkala).

7. Kalibrasi (kalibrasi suhu mesin seal, kalibrasi thermometer ruangan, \& kalibrasi dosing minyak).

8. Penetapan suhu minimal dan maksimal ruangan.

9. Penilaian supplier.

Perbaikan dilakukan dibulan Januari 2021, dan dilakukan pengambilan data kembali setelah dilakukan perbaikan pada bulan Februari 2021. 


\section{Data Defect Produk Setelah Perbaikan}

Data produk cacat setelah dilakukan perbaikan diperoleh pada proses packing minyak goreng kemasan pouch 1 L periode 1 - 28 Februari 2021. Dari jumlah produksi sebanyak 5.073.732 diperoleh jumlah cacat sebanyak 18.546. Dengan varian cacat yang masih sama seperti sebelum dilakukannya perbaikan. Dari data yang diperoleh didapatkan diagram $P$-chart dan sebagai berikut :

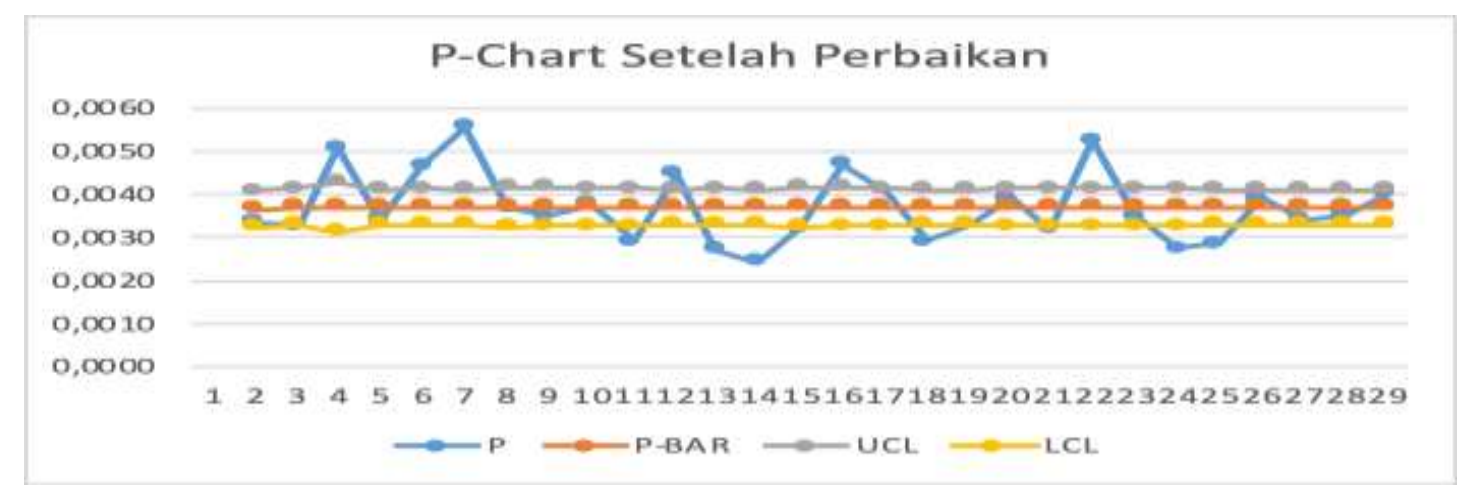

Gambar 14. Diagram P-Chart periode 1 - 28 Februari 2021

Dan berikut adalah diagram pareto yang diperoleh dari data cacat produk setelah dilakukan perbaikan :

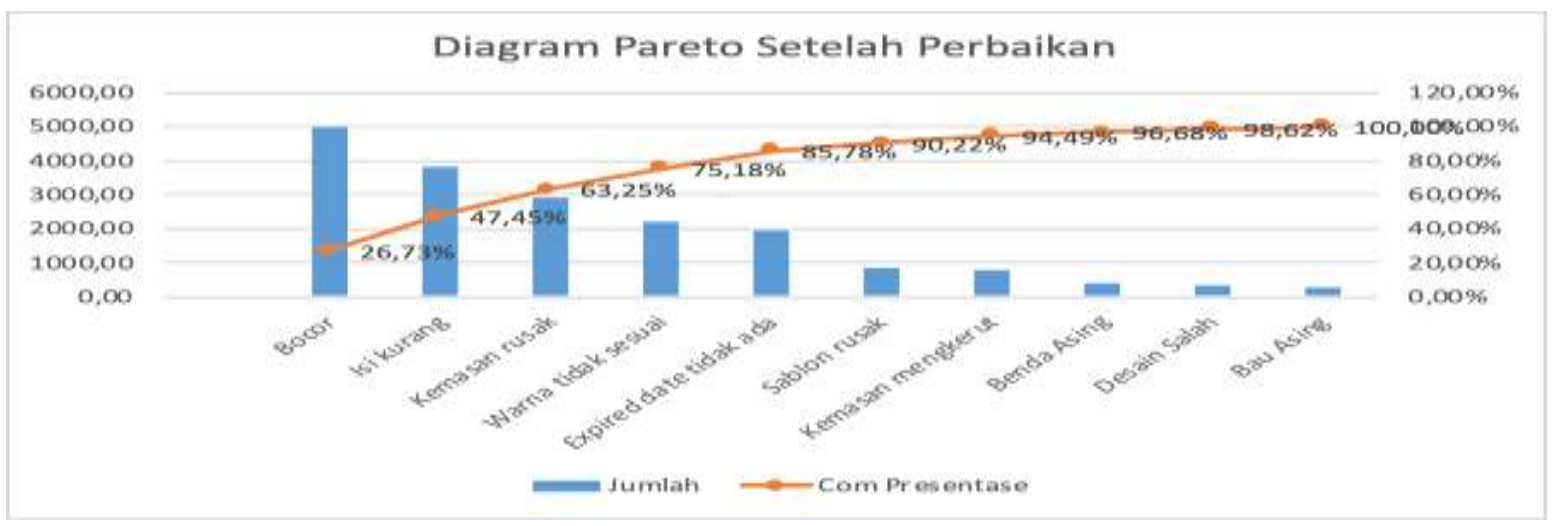

Gambar 15. Diagram Pareto periode 1 - 28 Februari 2021

Menganalisa tingkat Defect Per Million Oppertunitas perusahaan.

a. Menghitung DPU (Defect per unit)

$$
D P U=\frac{\text { jumlah defect }}{\text { jumlah produksi }}
$$

Menganalisa tingkat Defect Per Million Oppertunitas perusahaan. 
b. Menghitung DPU (Defect per unit)

$$
\begin{gathered}
D P U=\frac{\text { jumlah defect }}{\text { jumlah produksi }} \\
D P U=\frac{18.546}{5.073 .732} \\
D P U=0,003655
\end{gathered}
$$

c. Menghitung DPMO (Defect per million opportunities)

$$
\begin{gathered}
D P M O=\frac{\text { jumlah defect }}{\text { jumlah produksi }} \times 1.000 .000 \\
D P M O=0,003655 \times 1.000 .000 \\
D P M O=3.655
\end{gathered}
$$

Dari perhitungan diatas diperoleh DPU sebesar 0,003655 dan DPMO sebesar 3.655. Sedangan nilai level sigma diperoleh melalui perhitungan konversi nilai sigma dari DPMO dengan menggunakan Michrosoft Exel. Dengan rumus sebagai berikut :

Level sigma $=$ NORMSINV $\left(\frac{(1.000 .000-D P M O)}{1.000 .000}\right)+1,5$

Sehingga level sigma yang diperoleh adalah

Level sigma $=$ NORMSINV $\left(\frac{(1.000 .000-3,655)}{1.000 .000}\right)+1,5$

Level sigma $=4,18$

\section{Tahap Control}

Dari data yang diperoleh dari penelitian ini dapat dilihat dari kenaikan level sigma yaitu dari 3,99 menjadi 4.18 setelah dilakukan perbaikan. Berikut adalah histogram data nilai sebelum dan sesudah perbaikan:

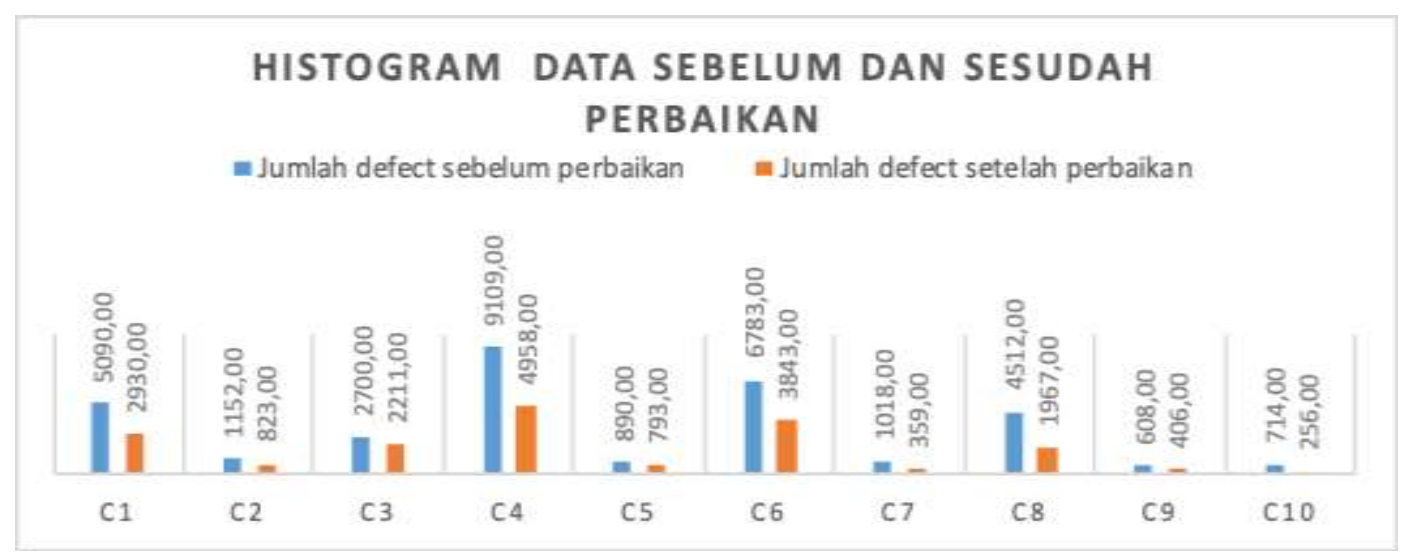

Keterangan : 
$\mathrm{C} 1$ : Kemasan rusak

C2 : Sablon rusak

C3 : Warna tidak sesuai yang diminta

C4 : Kemasan Bocor

C5 : Kemasan mengkerut
C6 : Isi tidak sesuai

C7 : Desain kemasan salah

C8 : Kode produksi / Expired date tidak ada

C9 : Adanya benda asing pada kemasan

C10 : Kemasan berbau

Terdapat penurunan pada semua jenis defect. Hal ini menunjukan alternatif perbaikan yang diajukan memiliki pengaruh dalam mengurai nilai cacat produk, yang berarti dapat menaikan level sigma. Untuk dapat mencegah defect produk yang tinggi maka tindak perbaikan yang telah dilaksanakan haruslah dilakukan secara konsisten. Seingga tingkat defect dapat terkontrol, dan tingkat kerugian perusahaan bisa ditekan.

\section{KESIMPULAN}

Setelah melakukan penelitian dan melakukan analisis data terhadap kualitas packing produk minyak goreng kemasan pouch 1 liter di PT. XYZ di gresik, maka dapat disimpulkan sebagai berikut :

1. Sebelum dilakukan perbaikan nilai sigma yang didapat yaitu 3,99 sigma dengan nilai DPU sebesar 0,006434 dan DPMO sebesar 6.364.

2. Terdapat 4 jenis defect yang masuk dalam CTQ yaitu bocor, isi kurang, kemasan rusak, dan expired date tidak ada.

3. Setelah melakukan tindakan perbaikan diperoleh nilai sigma seberas 4,18 dengan nilai DPU sebesar 0,003655 dan DPMO sebesar 3.655.

\section{UCAPAN TERIMA KASIH}

Saya ucapkan terima kasih kepaada PT. XYZ di Kabupaten Gresik karena mengizinkan kami untuk melakukan penelitian, terima kasi juga saya ucapkan kepada Universitas PGRI Adi Buana Surabaya atas dukungan yang diberikan dalam penulisan.

\section{DAFTAR PUSTAKA}

Assauri, Sofjan. 2004. Manajemen Pemasaran. Jakarta: Rajawali Press.

Didiharyono, Marsal, \& Bakhtiar. (2018, September). Analisis Pengendalian Kualitas Produksi Dengan MEtode Six Sigma Pada Industri Air Minum PT. Asera Tirta Posidonia, Kota Palopo. Sainsmat. 
Donald, L., Suzanne, B., \& Elaine, C. (2003). How to scope DMAIC projects. Quality Progress, 36 (1), $37-41$.

Fandy, Tjiptono. 2004. Manajemen Jasa, Edisi Pertama, Yogyakarta, Andi Offset

Gaspersz, V. (2002). Pedoman Implementasi Program Six Sigma Terintegrasi Dengan ISO 9001:2000, MBNQA, dan HACCP. Bogor: Gramedia. Retrieved from http://www.vincentgaspersz.com/wp-content/uploads/2020/02/BUKU-SIXSIGMA2002-VG-1.pdf.

Irwan dan Didi Haryono. 2015. Pengendalian Kualitas Statistik (Pendekatan Teoritis dan Aplikatif). Bandung: Alfabeta.

Izaah, N., \& Rozi, M. F. (2019, Maret 1). Analisi Pengendalian Kualitas Dengan Metode Six Sigma Dmaic Dalam Upaya Mengurangi Kecacatan Produk Rebana Pada UKM Alfiya Rebana Gresik. SOULMATH, 7.

Kotler, Philip. 2010.Manajemen Pemasaran: Analisis, Perencanaan, Implementasi dan Kontrol, (terjemahan Hendra Teguh dan Ronny A. Rusli AK),Jakarta:PT. Ikrar Mandiriabadi.

Kusumawati, A., \& Fitriyeni, L. (2017, Juli 1). Pengendalian Kualitas Proses Pengemasan Gula Dengan Pendekatan Six SIgma. Sistem dan Manajemen Industri, 1.

Linderman, K.; Zaheer, S; Choo, A. S (2003). "Six sigma: a goal-theoretic prespective: Journal of Operations Management, Vol 21, pp.: 193-203.

Manggala, D. (2005). Mengenal Six Sigma Secara Sederhana. Retrieved from https://gdmanggala.files.wordpress.com/2010/08/six-sigma-sederhana.pdf.

Park, S. H. (2002). "Six Sigma for productivity improvement : korean business corporation". Productivity Journal, Vol. 43, pp. : 173-183.

Pitoyo, D., \& Akbar, A. R. (2019, Februari 1). Analisis Pengendalian Kualitas Produk Dengan Metode Six Sigma dan Metode 5 Step Paln Di PT. Pikiran Rakyat Bandung. ReTIMS.

Rimantho, D., \& Mariani, D. M. (2017). Penerapan Metode Six Sigma Pada Pengendalian Kualitas Air Baku Pada Produksi Makanan. Jurnal Ilmiah Teknik Industri.

Sirine, H., \& Kurniawati, E. P. (2017, September 3). Pengendalian Kualitas Menggunakan Metode SIx SIgma (Studi Kasus Pada PT. Diras Concept Sukoharjo). AJIE, 2.

Shofia, N., Mustafid, \& Sudarno. (2015). Kajian Six Sigma Dalam Pengendalian Kualitas Pada Bagian Pengecekan Produk DVD Player PT. X. GAUSSIAN, 4. 
